\title{
The Impact of Tax System on Capital Investment: Evidence from Taiwan and Mainland China
}

\author{
Huang Li-Hua, Wang Jui-Chih*, Hsiao Hsing-Chin \\ Department of Accounting Information, National Taipei University of Business, Taiwan \\ Email: "jcwang@ntub.edu.tw
}

Received 16 October 2015; accepted 27 November 2015; published 30 November 2015

Copyright (C) 2015 by authors and Scientific Research Publishing Inc.

This work is licensed under the Creative Commons Attribution International License (CC BY). http://creativecommons.org/licenses/by/4.0/

c) (i) Open Access

\section{Abstract}

Taiwan initiated the integrated income tax system (IITS) in 1998. There were two parts in IITS including the dividend imputation tax credits (DITC) and $10 \%$ tax on the undistributed retained earnings (URE). The DITC provided the shareholders with a credit to offset personal tax on dividend income and eliminated the double taxation on corporate income. We examined the IITS impacts on the capital investments between Taiwan and Mainland China. We found that the companies with higher DITC ratio decreased the capital cost and resulted in more capital investments in Taiwan rather than Mainland China. However, the companies with higher URE bared extra 10\% tax burden and deteriorated the fund accumulation. The companies with higher URE ratio demonstrated higher capital investment in Taiwan opposed to the research hypothesis. The authority charging $10 \%$ tax on URE was intended to avoid the big shareholders tax evasion and reluctant to distribute to the shareholders. The tax addition policy did not accomplish the original policy mission. The retained earnings were still not distributed to the shareholders and maintained for internal fund needs. Compared to investment in Taiwan, the higher URE ratio presented less capital investment in Mainland China without statistics significant. Taiwanese policy of $40 \%$ net worth ceiling limitation on Mainland China investment was the possible reason for less investment. The ceiling limitation triggered the subsidiary company in Mainland China to not incline to wire the profit to the parent company in Taiwan and reinvest the profit in the plant expansion and $100 \%$ fully tax reimbursement. This tax addition charge did not affect the investment in Mainland China. Our empirical study supported that the DITC led to negative influence to the capital investment in Mainland China but not the only determinant of investment consideration. Our authority might modify the dividend wire back mechanism and cancel the $40 \%$ net worth ceiling of investment in order to attract more capital back to the efficiency market.

\footnotetext{
*Corresponding author.
} 
Keywords

\section{Integrated Income Tax System (IITS), Dividend Imputation Tax Credits (DITC), Undistributed Retained Earnings (URE) Tax, Capital Investment}

\section{Introduction}

At the end of 1970s, Mainland China implemented economy reform and Taiwanese businessmen started to invest in Mainland China as pioneers. Chinese open policy triggered the coast investment and attracted foreign direct investment. In 1980s, Taiwanese businessmen established the labor intensive industries in the four economy zones (Shenzhen, Zhuhai, Xiamen, and Shantou). In 1990s, Mainland China developed north coast to Shanghai from south as well as Taiwanese businessmen transformed from the capital intensive industries investment to the labor intensive industries investment. Based on the Investment Commission, the Ministry of Taiwan Economic Affairs, there were 237 cases (\$174 million USD) in 1991 and 497 cases in 2014 in terms of the Taiwanese investment approvals to Mainland China. Although the approval cases were declining since 2005, the approval amount was up to $\$ 10,277$ million USD in 2014. The Chinese official statistics announced that the Taiwanese investment to Mainland China was over 65\% of Taiwanese international trade.

More investment from Taiwan to Mainland China improved the economy development in Mainland China and promoted the Taiwanese industry enhancement. Meanwhile, the trading structure of Taiwan changed as well. According to the Council for Economic Planning and Development, the Executive Yuan of the Republic of Mainland China, before 1995, the Taiwanese investment to Mainland China contained the food, chemistry, textile, plastic, and electronic device and focused on resource-based industries and capital facility trade. However, after 1995, the Taiwanese investment to Mainland China emphasized on the larger scale investment and concerned on more sophisticated technology electronic industry. More capital flow transformed from Taiwan to Mainland China and the industry hollow consequence happened. Compared to Mainland China, the higher tax rate investment environment in Taiwan triggered the business movement to Mainland China. The authority might not only focus on the infrastructure development but also modify the tax system for lower corporate tax burden. Starting in 1998, Taiwan implemented the integrated income tax system (IITS). The purposes of the system were to eliminate the double taxation from the corporate income and decrease the corporate tax. IITS was aimed to facilitate the business in Taiwan for economy development. Taxes affect both the cost and the benefit of investment (Altshuler \& Fulghieri, 1994). Black, Legoria, and Sellers (2000) advocated that the impact of tax reforms on capital investment would facilitate the policymakers to make more informed decisions regarding tax policy as it affected capital investment.

After the IITS, the dividend imputation tax credit (DITC) eliminated the corporate double taxation, facilitated the investment intention, and lowered the corporate tax burden (Boyle, 1996; Huang Tien-Fu, 1998; Wang Jui-Chih, 2006). However, some studies opposed to the IITS; there were limitations to the tax decrease and reluctance to promote the investment (Hsu Wen-Yu, 1996). The IITS benefited to the high income persons and big corporation rather than the small-and-medium enterprises (SME) and individual investors (Cheng Yueh-Sui, 1996). In order to offset the tax loss of the DITC, the authority taxed the $10 \%$ of the undistributed retained earnings (URE) which deteriorated the capital accumulation and shortened the available operating funds dividend credit. This policy intensified the capital to non-continuing operation, impaired the long-term development, and mitigated the investment intention (Chang Keh-Jen, 1997; Chen Chung-Chin, 1997; Wang Chien-Tung, 2003). The IITS also cancels the $80 \%$ tax exemption to the transfer investment among the corporations and increases the corporate tax burden (Chen Chung-Chin, 1997). Meanwhile, the IITS eliminated the tax exemption incentives policies to the high technology industry for both URE up to the double paid-in capitals and five years corporate tax exemptions.

The DITC of the IITS was the credit from the corporate tax applied to the individual income tax. The domestic shareholders tax burden would be lower than the foreign shareholders. Therefore, when there was higher DITC, there were more capital investments in Taiwan than in Mainland China. Obviously, after the IITS, the tax system reform improved the investment environment in Taiwan. However, the policy of $10 \%$ levy to the URE increased the capital cost, decreased the capital accumulation, and impaired the investment decision. The results indicated that when the URE ratio was higher, the capital investment in Taiwan was higher opposed to the au- 
thority anticipation. The tax levy result did not meet the policy goal. The retained earnings were not distributed to the shareholders and maintained for internal fund needs.

Compared to investment in Taiwan, the higher URE ratio presented less capital investment in Mainland China without statistics significant. The insignificant reason was due to the Taiwanese policy of $40 \%$ net worth ceiling limitation to Mainland China investment. The ceiling limitation affected the subsidiary company in Mainland China reluctant to wire the profit back to the parent company in Taiwan, reinvested the profit in the plant expansion and gained $100 \%$ fully tax reimbursement as well. This tax addition charge did neither affect nor lessen the investment in Mainland China. Our study supported that the DITC impaired the investment in Mainland China. However, the DITC might not the only investment determinant to Chinese investment. Most tax reforms are composed of numerous changes with potentially offsetting effects (Black et al., 2000). Our empirical results would serve a reference for the authority to reconsider the policy of $40 \%$ net worth ceiling limitation.

Past research focused on the IITS to the investment decision effect: how the DITC ratio affected the fixed asset investment. However, the IITS in Taiwan included the DITC and 10\% surtax of URE. These two mechanisms were unique in the IITS in Taiwan. Therefore, it is our first research contribution to examine the Taiwanese IITS in terms of DITC and 10\% surtax of URE. Our second research contribution was to explore the capital investment decision between Taiwan and Mainland China based on the IITS influence rather than past studies focusing on the fixed assets investment. Our study may serve a guideline to the tax policy and capital investment decision.

In our study, we examined whether IITS enhanced the investment in Taiwan rather than investment in Mainland China. The remainder of this paper was organized as follows. In Section 2, we briefly reviewed studies related to tax effect to the capital investment. In Section 3, we presented the hypotheses development, the empirical model, and the variables measurement as well as the study design. In Section 4, we demonstrated and discussed our empirical results and analyses. Finally, conclusions and implications of our findings were discussed and limitation of this study was offered in Section 5.

\section{Literature Review}

Mainland China utilized cheaper labor and lower tax investment environment to attract foreign direct investment. Young (1988) suggested that the tax incentives increased the foreign direct investment. The statutory tax rate was 30\% in Mainland China. However, Mainland China offered the Taiwanese businesses for lower tax incentives such as five years tax exemptions and three years half-tax deductions. Taxes affect both the cost and the benefit of investment (Altshuler \& Fulghieri, 1994). The tax consideration was one of the Taiwanese businesses imperative concerns to invest either in domestic or in Mainland China investment. Past tax studies concentrated on fixed investment and lack of the capital investment themes. Carlson and Bathala (1994) discussed the Tax Reform Act (TRA) of 1986 for the issue between the investment tax credit and investment policy. During the TRA (1986-1987), the investment tax credit led positive influence to the investment. Before (1984-1985) and after the TRA (1988-1989), the investment tax credit would lower and decline the investment. When the investment tax credit affecting to the investment controlled, the investment ratio remained stable. The empirical study results of Carlson and Bathala (1994) were consistent to the works of Harrison (1990), Shoven (1990), Shoemaker (1991), and Rosacker and Metcalf (1993). They all supported that investment tax credit was an effective tool to promote the investment and decrease the capital cost.

Black, Legoria, and Sellers (2000) examined the effects of dividend imputation on corporate investment in New Zealand and Australia. Their empirical findings indicated that dividend imputation stimulated corporate investment in both countries. The more distributed dividends distributed brought higher impacts to the investment. Babcock (2000) developed a model to testify the DITC to multinational investment policy and result more domestic investment and less the foreign investment after the DITC implementation. Gupta and Hofmann (2003) examined how corporate tax changes affected the capital investment. They suggested the increasing tax burdens declined the capital expenditures. When the investment incentives increased to lower the tax, the capital expenditures surged.

The Integrated Income Tax System (IITS) had initiated in 1998 in Taiwan. Under this tax reform, there were two major policies including the DITC and 10\% surtax on the URE. The policy incurred mix consequences to the capital investment. The DITC decreases the Taiwan domestic shareholders tax burdens mostly. The highest marginal tax rate was from $55 \%$ to $40 \%$. The tax rate decreased $15 \%$ due to the DITC and promoted the domes- 
tic investment incentive. However, the authority would compensate the tax loss of DITC policy by charging the $10 \%$ surtax on the URE. This policy mitigated the company to avoid individual tax by not distribute the retained earnings. Nevertheless, the surtax deteriorated the capital accumulation, lowered the investment intention, impaired the normal capital market development, and decreased the operating fund (Chen Tu-An, 1985; Chang Keh-Jen, 1997; Chen Chung-Chin, 1997).

The related IITS policy affected the investment. Chen Chung-Chin (1997) examined the IITS consequence and found the "tax-exempt" effect as well as to make the fund flow from investment to savings and other non-investment means. The IITS canceled the tax exemption of $80 \%$ transferred-investment gains within corporations. If all the transferred-investment gains taxed, the tax burden increased. However, under the imputation dividend system, the tax exemption of $80 \%$ transferred-investment gains would be replaced by the corporate tax credits. There were more benefits for more transferred investment layers. Therefore, there were less impact to the shareholders and corporations (Chen Chung-Chin, 1997). Wu Chiuh-Wo (1997) found that after IITS the former tax incentives shrunk. The former industry promotion tax policies included the tax exemptions of the URE within the double paid-in capitals and 5 years corporate tax exemptions.

Chang Jui-Tang, Tseng Yu-Chi, and Huang Tien-Fu (1999) surveyed the IITS effects on investment. They found there were positive impacts of DITC on investment and negative impacts of $10 \%$ surtax of URE on investment. The modified tax incentive policies had no significant effects on investment. However, Wang ChienTung (2003) demonstrated that after the IITS implementation, the 10\% surtax of URE had negative influence to the investment expenditure than the positive DITC. The $10 \%$ surtax addition impaired the capital accumulation and incurred negative capital investment effect. Wang Jui-Chih (2006) examined the periods before and after the IITS implementation to the capital investment influence. Wang Jui-Chih (2006) also found the companies with higher DITC ratios decreased the shareholders tax burden and lower the shareholder capital cost. There was an increase of the investment intention. Therefore, after IITS, higher DITC companies had higher capital investment ratio than before IITS without statistics significance. However, before IITS, the capital cost of the internal retained earnings was lower than the debt or stock financing. The companies would prefer maintaining the retained earnings rather than distributing to the shareholders. Under IITS, the URE were required to charge $10 \%$ surtax. If there were more retained earnings, there were more retained earnings taxes. When there were increasing costs of the retained earnings, there was less investment intention. When there were higher URE, there were higher capital cost of retained earnings and lesser investment intention (Wang Jui-Chih, 2006). Therefore, under IITS, the companies with higher URE ratio had lesser capital investment ratios than before IITS.

\section{Research Design}

\subsection{Hypotheses Development}

Under IITS, the DITC mitigated the double taxation of the dividend income. The paid corporate tax was deductible in the individual shareholder claim. The IITS encouraged the business to distribute more dividends to the shareholders. The policy purpose was to decrease the retained earnings treated as the avoidance of the shareholder tax burden. Meanwhile, the capital costs derived from the shareholders were lowered. Black et al. (2000) found both in New Zealand and Australia, the IITS led the increasing capital investment. Chang Jui-Tang et al. (1999) stated that the DITC from IITS decreased the shareholder tax burden and lowered the financing capital cost from the shareholders. The business investment incentive was enhanced. In contrast to the corporate taxes levied in Mainland China, there was no DITC applied from the investment of Mainland China. The capital investment of Mainland China was decreased. In our study, we investigated the impact from the shareholder dividend credit to the investment decision between Taiwan and Mainland China. Therefore, we proposed the following hypotheses:

H1-1: The business with higher dividend imputation tax credits (DITC) ratios has higher capital investment in Taiwan.

H1-2: The business with higher dividend imputation tax credits (DITC) ratios has lower capital investment in Mainland China.

Under IITS, the Ministry of Finance levied the 10\% surtax of URE in order to offset the tax losses derived from the DITC. The surtax of URE reduced the capital accumulation and increased the retained capital burden. If the internal capital was short, the business needed to finance externally. The policy would lead to both in- 
vestments in Taiwan and Mainland China down (Chen Tu-An, 1985; Chang Keh-Jen, 1997; Chen Chung-Chin, 1997). Therefore we proposed the following hypotheses:

H2-1: The higher undistributed retained earnings (URE) ratios lead lower capital investment in Taiwan.

H2-2: The higher undistributed retained earnings (URE) ratios lead lower capital investment in Mainland China.

\subsection{Research Models}

We explored the effects of Taiwanese and Chinese investment decisions based on IITS. Besides the DITC and URE, the firm-specific characteristics were measured in this study as well. Therefore, we applied the simultaneous regression models ${ }^{1}$ to estimate the regression coefficients as follows:

$$
\begin{aligned}
\text { RTaiwanI }_{\mathrm{it}}= & \alpha_{0}+\alpha_{1} \mathrm{ITC}_{\mathrm{it}}+\alpha_{2} \text { RUDIS }_{\mathrm{it}}+\alpha_{3} \text { RChinal }_{\mathrm{it}}+\alpha_{4} \text { TInvRev }_{\mathrm{it}}+\alpha_{5} \mathrm{ETR}_{\mathrm{it}}+\alpha_{6} \mathrm{DE}_{\mathrm{it}} \\
& +\alpha_{7} \mathrm{GROWTH}_{\mathrm{it}}+\alpha_{8} \mathrm{SIZE}_{\mathrm{it}}+\alpha_{9} \mathrm{CINT}_{\mathrm{it}}+\alpha_{10} \mathrm{DOIL}_{\mathrm{it}}+\alpha_{11} \mathrm{MTaiwan}_{\mathrm{it}}+\mathrm{e}_{\mathrm{it}} \\
\text { RChinaI }_{\mathrm{it}}= & \beta_{0}+\beta_{1} \mathrm{ITC}_{\mathrm{it}}+\beta_{2} \mathrm{RUDIS}_{\mathrm{it}}+\beta_{3} \mathrm{RTaiwanI}_{\mathrm{it}}+\beta_{4} \mathrm{CInvRev}_{\mathrm{it}}+\beta_{5} \mathrm{ETR}_{\mathrm{it}}+\beta_{6} \mathrm{DE}_{\mathrm{it}} \\
& +\beta_{7} \text { GROWTH }_{\mathrm{it}}+\beta_{8} \mathrm{SIZE}_{\mathrm{it}}+\beta_{9} \mathrm{CINT}_{\mathrm{it}}+\beta_{10} \mathrm{DOIL}_{\mathrm{it}}+\beta_{11} \mathrm{MChina}_{\mathrm{it}}+\mathrm{e}_{\mathrm{it}}
\end{aligned}
$$

where: for firm $i$, at time t. $\alpha_{0}\left(\beta_{0}\right)$ and $\alpha_{1} \sim \alpha_{11}\left(\beta_{1} \sim \beta_{11}\right)$ were the interceptions and coefficients of regression. RTaiwanI ${ }_{\mathrm{it}}$ was the ratio of capital investment in Taiwan divided by the parent company total assets for firm $i$, at time $t$. RChinal ${ }_{\mathrm{it}}$ was the ratio of capital investment in Mainland China divided by the parent company total assets for firm $i$, at time $t$. ITC $_{\text {it }}$ and RUDIS it $_{\text {it }}$ were the IITS variables: the DITC ratio and ratio of URE. TInvRev $_{i t}$ was the investment revenue from Taiwan divided by the parent company income before taxes. $\operatorname{CInvRev}_{\text {it }}$ was the investment revenue from Mainland China divided by the parent company income before taxes. $\mathrm{ETR}_{\mathrm{it}}, \mathrm{DE}_{\mathrm{it}}, \mathrm{GROWTH}_{\mathrm{it}}, \mathrm{SIZE}_{\mathrm{it}}, \mathrm{CINT}_{\mathrm{it}}$ and $\mathrm{DOIL}_{\mathrm{it}}$ were the firm-specific characteristics variables in terms of the ratio of effective tax rate, ratio of debt to equity, ratio of growth, size of firm, ratio of capital intensity and dummy variable of net operation losses. In order to control the macro economic effects to the

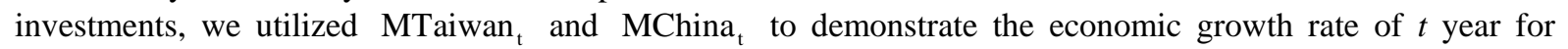
Taiwan and Mainland China.

\subsection{Variables Measurement}

\subsubsection{Dependent Variables}

There were two dependent variables applied in this study. The first one was the ratio of capital investment in Taiwan (RTaiwanI). We applied the capital investment in Taiwan divided by the parent company total assets (long-term investment book value applying the equity method). Another one was the ratio of capital investment in Mainland China (RMainland ChinaI). The capital investment in Mainland China was divided by the parent company total assets (long-term investment book value applying the equity method).

\subsubsection{Independent Variables}

In this study, there are two sections of independent variables: IITS variables and the firm-specific characteristics variables.

\subsubsection{IITS Variables}

Ratio of dividend imputation tax credits (ITC): The DITC was to eliminate the double taxation of the dividend income derived from the corporate and individual income taxes. For Taiwanese shareholders, the DITC was a credit applied to the individual income tax from the paid corporate income tax on dividend distributions. The DITC reduced the Taiwanese shareholders tax and lowered the capital cost of the corporate to the domestic shareholders. However, the DITC was not applied to the investors whom invested out of Taiwan. Therefore, the paid corporate income tax from Chinese investment was not deductible to the domestic shareholders. Based on the Income Tax Regulation, No. 66-6 in Taiwan, the DITC rate was determined on the date of distribution of dividend or earnings. The DITC rate was the individual shareholder DITC account balance to the accumulated

\footnotetext{
${ }^{1}$ We applied the seemingly unrelated regressions (SUR) to estimate each sample coefficient in order to control the residual correlation among different companies.
} 
$\mathrm{URE}^{2}$. We anticipated the DITC ratio correlated positively to the Taiwanese capital investment and negatively to the Chinese capital investment.

Ratio of undistributed retained earnings (RUDIS): The authority levied the $10 \%$ surtax of URE to offset the tax losses of DITC. The 10\% surtax of URE was included in the corporate tax. Therefore, we measured the URE ratio applying the net income after income tax, lessened the salaries of board of directors, cash bonus to employees and common stocks (preferred stocks) dividends by the net income after income tax. When there was higher ratio of URE, there was higher charged retained earnings tax. The surtax of URE reduced the capital accumulation and lowered the investment intension. There were negative correlations among the URE to the capital investment both in Taiwan and Mainland China.

\subsubsection{Firm-Specific Characteristics Variables}

Ratio of investment revenue in Taiwan (TInvRev): We utilized the investment revenue from Taiwan divided by the parent company income before taxes. When the firm invested in the subsidiary company which owned over $25 \%$, the parent company needed to apply the equity method to recognize the investment revenue. When there were more investment revenues, there were more invested capitals.

Ratio of investment revenue in Mainland China (CInvRev): We applied the investment revenues from Mainland China divided by the parent company income before taxes. There was a regulation to limit the Chinese investment up to $40 \%$ of net worth. The dividend wire back to Taiwan was taxable. When the Taiwanese businesses earned the profit, they were reluctant to wire back to the parent company in Taiwan. They would continue to invest the subsidiary company in Mainland China. When there were more investment revenues, there were more invested capitals.

Ratio of effective tax (ETR): The corporate effective rate was to capture the impacts of the investment decisions. The ratio was measured as the income taxes expense divided by net income before income taxes expense. The effective (marginal) tax rate affected the capital investment. When there was no tax, there was no taxable income. When the corporate had more taxable income, there would generate more capital investment.

Ratio of debt to equity (DE): We applied each firm's debt-to-equity ratio to evaluate the effects of financial leverage. The resource of the investment capital was either from debt or stock. Before IITS, the interest expense of the debt was expensed for tax saving effect. Therefore, the company would prefer debt rather than stock financing. The capital structure was affected by IITS. After IITS, the authority tried to lessen the tax impact to the capital structure and levy the $10 \%$ surtax on URE. This policy was to decrease the tax rate gap between the corporate and individual income taxes. The tax avoidance from the retained earnings was mitigated. Black et al. (2000) found that capital structure affected the investment. When the DE ratio was higher, there was higher debt burden. There was lesser internal capital accumulation and there was conservative investment intension as well.

Ratio of growth (GROWTH): Collins and Kothari (1989) and Black et al. (2000) asserted that the market-to-book ratio captured the difference between a firm's return on both existing and future assets and its required rate of return on equity. A lower ratio indicated greater investment opportunities expected to yield returns in excess of the required rate of return. Carlson and Bathala (1994) utilized the market of equity to the book value of assets to measure the investment opportunities (Tobin's q) and found there was positive relationship with capital investment. Therefore, we applied the ratio of the sum of the book value of long-term debt and the market value of equity to the book value of the total assets. We anticipated that the higher growth ratio led higher capital investment.

Company size (SIZE): We applied the natural log of total asset to measure the size of the firm. The size of the firm affected the ability to finance additional investment (Carlson \& Bathala, 1994; Black et al., 2000). We anticipated that the larger size of the firm led more capital investment.

Ratio of capital intensity (CINT): The decision to capital investment was not only affected by the tax system but also impacted by the firm's industry and business operating type. The manufacturing and high technology industries required higher capital investment on the plants, properties, and equipments rather than the service industry. Black et al. (2000) found that capital investment with high capital intensity affected more by the tax system change rather than the ones with relatively lower capital intensity. We thus measured the capital intensity

${ }^{2}$ When the rate was over the tax credit rate, the tax credit rate superseded the ceiling charge. There were three kinds of rate ceilings. 1) The accumulated undistributed retained earning without $10 \%$ surtax corporate tax would be imposed for $33.33 \%$; 2) The accumulated undistributed retained earning with $10 \%$ surtax corporate tax would be imposed for $48.15 \%$; and 3) if there were both accumulated undistributed retained earnings with and without $10 \%$ surtax charged situations, the proportion method was applied and calculated as the previous two regulations mentioned. 
as the ratio of fixed assets to total assets. The costs of the capital and labor from Mainland China were relatively cheaper than Taiwan. Therefore, the businesses with higher of capital intensity resulted higher capital investment ratio in Mainland China than in Taiwan.

Net operating income loss (DOIL): When there was lower taxable income, there was possible to have increasing net sales loss. When the operating income loss decreased, the DITC would be lower. The IITS impact was lessened and the capital investment would be lesser than before IITS. We applied the dummy variable as proxy. When the sales were lesser than the operating expenses, the net operating income loss equaled to 1 and 0 otherwise. We would examine whether the operating situation would impact the investment decision either in Mainland China or Taiwan. In order to control the effects of the macro economics to the capital expenditure, we applied MTaiwan and MMainland China to demonstrate the economic growth rates in Taiwan and Mainland China.

\subsection{Data}

We applied the pooled, cross-sectional, and firm-year data from 1998 to 2008. The financial data was derived from the listed and over-the-counter (OTC) company database of the Taiwan Economic Journal (TEJ) database. There were 102,834 original investment data including 22,534 non-Taiwan investment and 53,705 investment revenue applied cost method or lower-of-cost-or-market method. We got 26,595 investment adopted equity method. After merging the investment of the same year, there were 7285 firm-year observations in Taiwan. Meanwhile, there were 7368 capital investment and investment revenues data from Mainland China investment database. We applied the simultaneous regression models and retrieved 14,382 firm-specific variable data from the listed and OTC financial database. At final, we applied 3538 valid firm-year observations as study samples.

\section{Results}

The purposes of the integrated income tax system (IITS) were to mitigate the dividend double taxations from corporate and individual income taxes and charge $10 \%$ surtax of URE to motivate the retained earnings distribution. The authority initiated IITS to provide better tax environment and enhance the capital investment activities. Our study applied the listed and the over-the-counter (OTC) data to examine IITS effects to both capital investment in Taiwan and Mainland China

\subsection{Descriptive Statistics}

Figure 1 revealed the capital investment both in Taiwan and in Mainland China. From 1998 to 2005, the means of the capital investment in Taiwan (RTaiwanI) were higher than in Mainland China (RMainland ChinaI). After 2006, the capital investment from Taiwan to Mainland China was greater than the Taiwan domestic investment. Based on Figure 1, there was trend of capital investment from Taiwan to Mainland China. However, the domestic investment trend in Taiwan was slow. According to Table 1, the descriptive statistics demonstrated that the mean (median) of ratio of capital investment in Taiwan (RTaiwanI) was 9.58\% (5.42\%), higher (lower) than the mean (median) of ratio of capital investment in Mainland China (RMainland ChinaI) 8.84\% (4.89\%). There was a regulation of $40 \%$ limit of capital to the investment of Mainland China. The profit wire back from Mainland China to Taiwan was taxable. The regulation would trigger the Taiwanese businesses to reinvest the profit in Mainland China and reluctant to wire back to Taiwan. The amount of capital investment was possible underestimated.

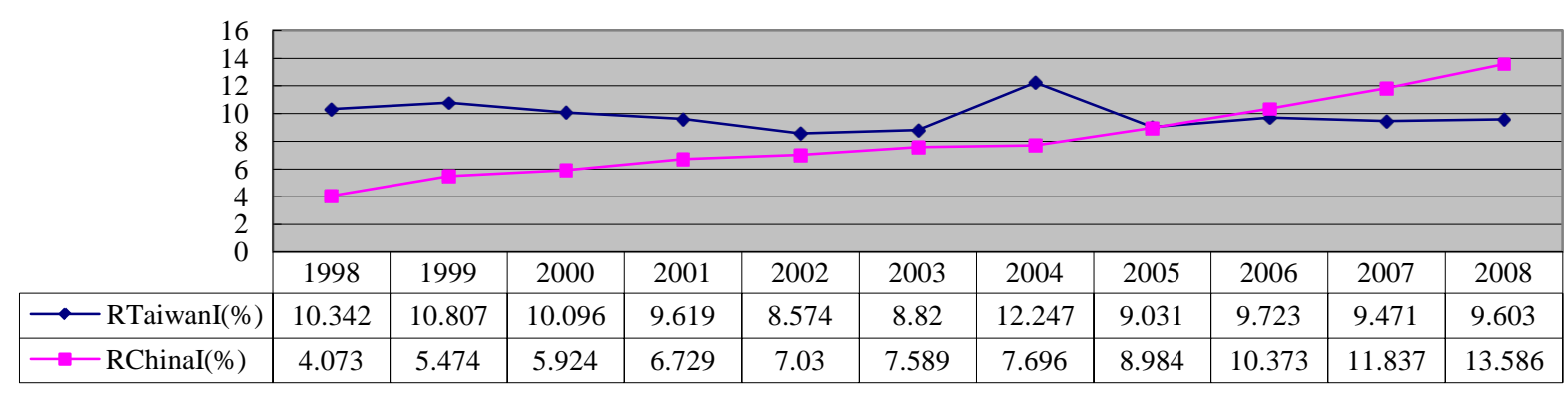

Figure 1. Ratios of capital investment in Taiwan and Mainland China. 
Table 1. Descriptive statistics.

\begin{tabular}{ccccccc}
\hline Variables & Minimum & Q1 & Mean & Median & Q3 & Maximum \\
\hline RTawinI (\%) & 0 & 1.845 & 9.583 & 5.420 & 12.922 & 99.540 \\
RMainland ChinaI (\%) & 0 & 1.238 & 8.844 & 4.885 & 12.504 & 123.978 \\
ITC (\%) & 0 & 0 & 11.147 & 6.820 & 19.740 & 48.150 \\
RUDIS (\%) & 0 & 11.100 & 44.866 & 28.915 & 100.000 & 100.000 \\
TInvRev (\%) & -10.000 & -2.821 & -10.521 & 1.081 & 13.928 & 6676.42 \\
CInvRev (\%) & -10.000 & -5.260 & -35.447 & 0 & 9.980 & 7547.77 \\
ETR (\%) & 0 & 0 & 11.605 & 7.590 & 17.760 & 100.00 \\
DE (\%) & 0 & 39.33 & 81.057 & 64.205 & 95.870 & 2.000 \\
GROWTH (\%) & 0 & 50.93 & 97.245 & 76.195 & 118.670 & 1.000 \\
SIZE (log) & 11.143 & 14.965 & 15.812 & 15.634 & 16.440 & 20.290 \\
CINT (\%) & 0 & 10.300 & 23.716 & 21.235 & 33.950 & 83.130 \\
DOIL (1,0) & 0 & 0 & 0.188 & 0 & 0 & 1.000
\end{tabular}

Note 1: Definition of variables; RTaiwanI: Ratio of Capital Investment in Taiwan. RMainland ChinaI: Ratio of Capital Investment in Mainland China. ITC: Ratio of imputation tax credits. RUDIS: Ratio of Undistributed Earnings. TInvRev: Ratio of Investment Revenue in Taiwan. CInvRev: Ratio of Investment Revenue in Mainland China. ETR: Ratio of Effective Tax. DE: Ratio of Debt to Equity. GROWTH: Ratio of Growth. SIZE: Log of the size. CINT: Ratio of Capital Intensity. DOIL: Dummy variable of Net Operating Income Loss. MTaiwan: Ratio of Taiwan Economic Growth. MMainland China: Ratio of Mainland China Economic Growth.

In 1998, Taiwan initiated IITS. There were two mechanisms of IITS: DITC and 10\% surtax of URE. The mean of DITC (ITC) was $11.15 \%$ slightly lower than the corporate effective rate (11.60\%). The DITC diminished the dividend double taxation and reduced the corporate average tax rate. The mean of the URE (RUDIS) was $44.87 \%$. The ratio was pretty higher even there was a $10 \%$ surtax charge regulation. Taiwanese businesses still sustained more retained earnings in order to reduce the external financial situation and provide internal funding needs.

Regarding the firm-specific characteristics analyses, the mean (median) of ratio of investment revenue from Taiwan (TInvRev) was $-10.52 \%$ (1.081\%) higher than the mean (median) of ratio of investment revenue from Mainland China (CInvRev) $-35.45 \%$ (0). The mean of the effective tax rate (ETR) was $11.60 \%$ lower than the statutory 25\% tax rate. Most of businesses enjoyed excessive tax benefits. The businesses actually paid fewer corporate taxes. The mean of the debt-equity ratio (DE) was $81.06 \%$. The mean of the investment growth ratio (GROWTH) was $97.24 \%$. The mean of the company size (SIZE) was 15.81. The mean of the capital intensity (CINT) was 23.71\%. Most of the sample businesses would invest the capital inclined to the labor intense industries. The mean of the company size was 15.81 and the median was 15.63, indicating there was no investment scale significant difference for the listed and OTC businesses to Mainland China. Pertaining to the economic growth, the mean of the Chinese economic growth rate (MMainland China) was $9.77 \%$ over the Taiwanese economic growth rate (MTaiwan) 3.66\%.

\subsection{Correlation Coefficients}

Table 2 demonstrated the Pearson and Spearman correlation coefficients for the research variables. There was positive relationship but not statistics significance between the ITC and capital investment ratio in Taiwan (RTaiwanI) in the Spearman correlation coefficient. However, there was negative and statistics significance relationship between the ITC and the capital investment ratio in Mainland China (RMainland ChinaI) consistent to the hypothesis. Under IITS, the shareholders from Taiwan might apply the DITC to Taiwanese investment but not in Chinese investment. Therefore, the Taiwanese investment was greater than the Chinese investment. 


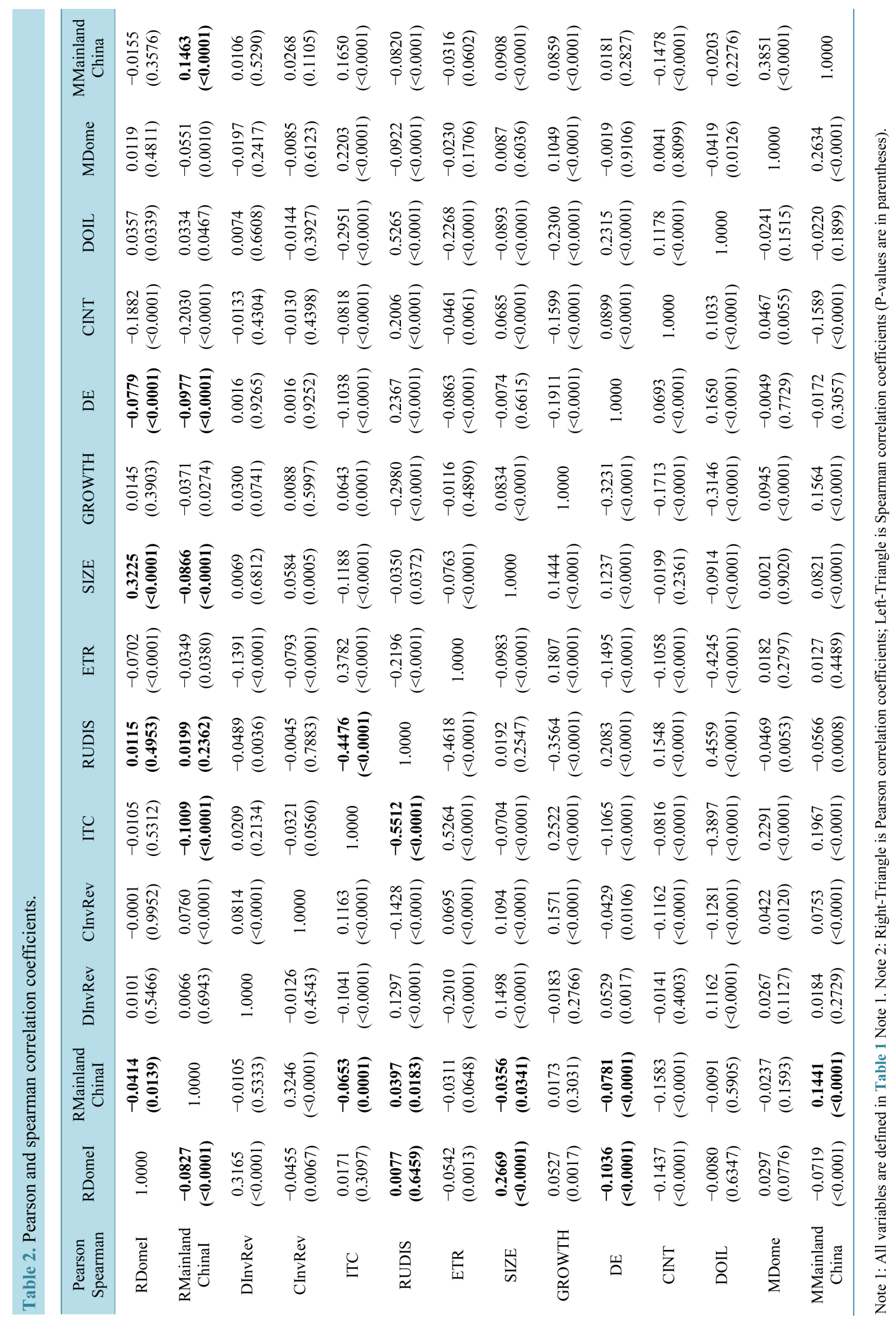


There was positive statistics significance relationship but only in the Spearman correlation coefficient between the URE (RUDIS) and capital investment ratio in Mainland China (RMainland ChinaI) opposed to the hypothsis. There were negative statistics significance relationship between the ratio of debt to equity (DE) and capital investment ratio both in Mainland China (RMainland ChinaI) and in Taiwan (RTaiwanI). We suggested that the businesses prioritized the financing capital cost consideration. Although more URE led more levied surtax, the surtax was lower than the financing cost. The businesses would prefer to pay the $10 \%$ surtax and sustain more retained earnings for future investment needs.

When the capital investment revenue ratio in Mainland China (CInvRev) was higher, there was higher capital investment ratio in Mainland China (RMainland ChinaI). The larger size companies had higher investment ratio in Taiwan and lower investment ratio in Mainland China. The higher capital intensity (CINT) industry had lower capital investment ratio. The correlation coefficients of the rest variables were between -0.47 to 0.56 . The multicollinearity did not appear to be a problem in the regression analysis.

\subsection{Multivariable Regression Analyses}

The multinational businesses would consider different capital investment at different investment locations. In this study, we examined whether the Taiwanese businesses influenced by the DITC and URE when they both invested in Taiwan and Mainland China. We conducted the empirical study by the regression analyses. Based on Table 3, there were positive statistics significance between the regression coefficients of the ITC and the capital investment ratio in Taiwan (RTaiwanI). However, there were negative statistics significance between the regression coefficients of the ITC and the capital investment ratio in Mainland China (RMainland ChinaI). After IITS, the Taiwanese shareholders might apply the DITC rather than the Chinese investor. The IITS encouraged the Taiwanese domestic capital investment and reduced the Chinese capital investment. The result supported our first hypothesis.

Table 3. Regression results by capital investment ratios.

\begin{tabular}{|c|c|c|c|c|c|}
\hline \multirow{3}{*}{ Variables } & \multirow{3}{*}{ Pred. Sign } & \multicolumn{4}{|c|}{ Model (1.1) and (1.2) } \\
\hline & & \multicolumn{2}{|c|}{ Y: RTaiwanI } & \multicolumn{2}{|c|}{ Y: RMainland ChinaI } \\
\hline & & Parameter & t value (p value) & Parameter & t value (p value) \\
\hline Intercept & ? & -34.485 & $-14.31(<0.0001)$ & 12.857 & $5.06(<0.0001)$ \\
\hline ITC &,+- & 0.056 & $3.19(0.0015)^{* *}$ & -0.131 & $-7.77(<0.0001)^{* *}$ \\
\hline RUDIS & - & 0.017 & $2.77(0.0056)^{* *}$ & -0.001 & $-0.08(0.9368)$ \\
\hline RTaiwanI & - & & & -0.128 & $-7.83(<0.0001)^{* *}$ \\
\hline RMainland ChinaI & - & -0.149 & $-8.75(<0.0001)^{* *}$ & & \\
\hline TInvRev & + & -0.001 & $-0.06(0.9529)$ & & \\
\hline CInvRev & + & & & 0.001 & $4.39(<0.0001)^{* *}$ \\
\hline ETR & + & -0.045 & $-3.56(0.0004)^{* *}$ & 0.002 & $0.17(0.8643)$ \\
\hline $\mathrm{DE}$ & - & -0.013 & $-6.72(<0.0001)^{* *}$ & -0.014 & $-7.83(<0.0001)^{* *}$ \\
\hline GROWTH & + & -0.007 & $-2.97(0.0030)^{* *}$ & -0.012 & $-5.16(<0.0001)^{* *}$ \\
\hline SIZE & + & 3.163 & $21.90(<0.0001)^{* *}$ & -0.466 & $-3.08(0.0021)^{* *}$ \\
\hline CINT &,-+ & -0.184 & $-15.99(<0.0001)^{* *}$ & -0.146 & $-12.82(<0.0001)^{* *}$ \\
\hline DOIL & ? & 2.672 & $4.88(<0.0001)^{* *}$ & 0.843 & $1.58(0.1142)$ \\
\hline MTaiwan & + & 0.029 & $0.39(0.6947)$ & & \\
\hline \multirow[t]{2}{*}{ MMainland China } & + & & & 1.195 & $9.37(<0.0001)^{* *}$ \\
\hline & & \multicolumn{4}{|c|}{ System Weighted R-Square $15.62 \%$} \\
\hline
\end{tabular}

Note 1: All variables are defined in Table 1 Note 1 . Note $2: * 5 \%$ significance level; **1\% significance level. 
In order to offset the loss of the DITC, there was 10\% surtax of URE. This regulation increased the capital cost burden and reduced the capital accumulation. Based on Table 3, there was positive statistics significance between the URE ratio (RUDIS) and the capital investment ratio in Taiwan (RTaiwanI) opposed to the hypothesis. The Figure 2 demonstrated that the URE ratio of after IITS (from 1998 to 2008) was 46.68\% over the period before IITS (from 1988-1997) (37\%) with statistics significant (t value: 8.70 and $p$ value $<0.0001$ ). The cash dividend distribution rate incurred $55.98 \%$ before IITS. The rate was $51.10 \%$ after IITS with statistics significant ( $\mathrm{t}$ value: -3.64 and $\mathrm{p}$ value 0.0003 ). We might conclude that the $10 \%$ surtax of URE mission failed since the businesses still sustained the retained earnings for internal fund usage.

When the URE ratio (RUDIS) was higher, the capital investment ratio in Mainland China (RMainland ChinaI) was lower but not statistics significance. The reason might be the official investment regulation limit up to $40 \%$ of net worth. This limitation triggered the Chinese subsidiary reluctant to wire back the profit to Taiwanese parent company. The Taiwanese businesses would invest the profit for plant expansion in Mainland China. The empirical results did not support our second hypothesis. With limited investment capital resources, there were trade-off effects for different capital investment locations. Based on Table 3, the capital investment ratios between Taiwan and Mainland China exhibited substitute relationship. When the capital investment in Taiwan increased, the capital investment in Mainland China decreased, vice versa. There was positive statistics significance relationship between the investment revenues ratio in Mainland China (CInvRev) and the capital investment ratio in Mainland China (RMainland ChinaI). When the gained investment revenues from Mainland China were more, there was higher capital investment in Mainland China.

Regarding the other firm-specific characteristics to the capital investment impacts, we assumed that the higher effective rate (ETR) might lead higher capital investment ratio. However, the empirical results exhibited a negative relationship. The possible reason was due to the tax environment influence. The corporate tax rate was $25 \%$ in Taiwan and there were various tax deductions and exemptions in Mainland China. The effective corporate tax rate in Mainland China was actually lower than in Taiwan. Once the Taiwanese businesses gained the profits in Mainland China, they would reinvest in Mainland China for 100\% tax back redemption. The interesting results exhibited a loss at the book but increasing capital investment. When the debt to equity (DE) ratio was higher, there was higher debt burden. The external financial capital cost was higher than the internal fund. The investment opportunity would decrease as well as the lesser capital investment. The higher investment growth (GROWTH) company demonstrated lesser capital investment ratio opposed to the research hypothesis. We suspected that the inferior and deteriorating investment environment in Taiwan promoted higher and growing industry investment overseas.

The larger size (SIZE) company had higher capital investment in Taiwan. However, the smaller size company had higher capital investment in Mainland China. The smaller company had advantages in Mainland China due to the cheaper capital and labor than Taiwan. There were higher flexibilities in terms of personnel and manufacturing. Most of early Taiwanese pioneers businesses to Mainland China were the small-and-medium enterprises (SME). The higher capital intensity (CINT) companies required more capital. The limited land and higher labor cost in Taiwan mitigated businesses investment. Therefore, the higher capital intensity company had lower capital investment ratio. The net operating income loss (NOIL) company would continue to invest in Taiwan than Mainland China. The company without net operating income loss would increase the Chinese capital investment. Regarding the impacts of the macro-economic to the investment decision, the economic growth rate of Mainland China was higher than Taiwan. Meanwhile, the businesses had higher percentages in the capital investment ratios in Mainland China.

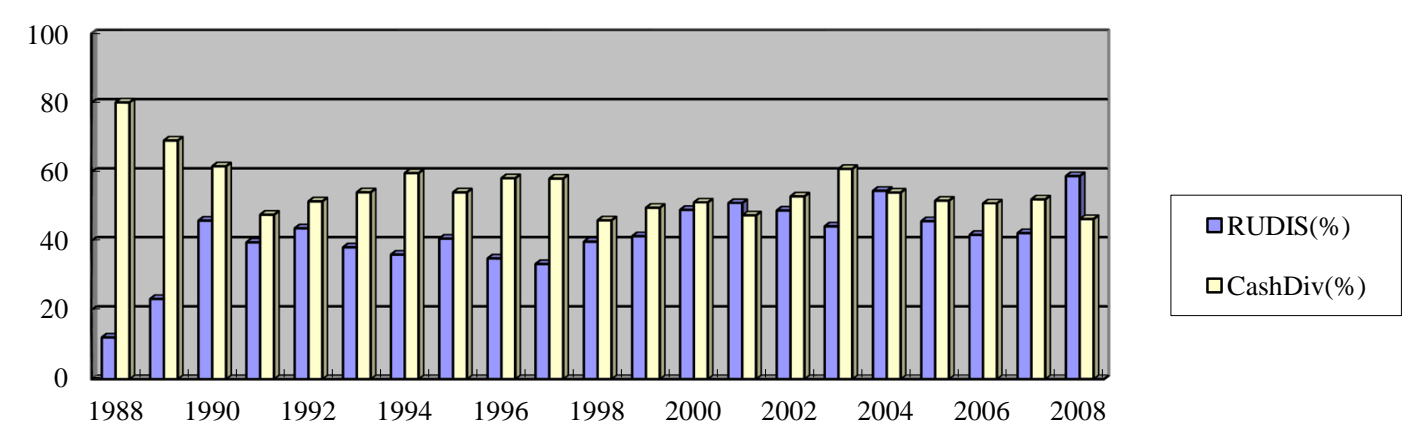

Figure 2. Distribution of URE Ratio (RUDIS) and Cash Dividend (CashDiv). 


\subsection{Additional Tests}

In order to be robustness of the study, we conducted additional analyses to change the models (1.1) and (1.2) into (2.1) and (2.2). We measured the multidimensional levels of investment in terms of investment numbers instead of the investment amounts. We examined the IITS impact to the investment amounts both in Taiwan and Mainland China. Here were the research models:

$$
\begin{aligned}
& \text { NTaiwan }_{\text {it }}=\alpha_{0}+\alpha_{1} \text { ITC }_{\text {it }}+\alpha_{2} \text { RUDIS }_{\text {it }}+\alpha_{3} \text { NChina }_{\text {it }}+\alpha_{4} \text { TInvRev }_{\text {it }}+\alpha_{5} \text { ETR }_{\text {it }}+\alpha_{6} \mathrm{DE}_{\text {it }} \\
& +\alpha_{7} \text { GROWTH }_{\mathrm{it}}+\alpha_{8} \mathrm{SIZE}_{\mathrm{it}}+\alpha_{9} \mathrm{CINT}_{\mathrm{it}}+\alpha_{10} \mathrm{DOIL}_{\mathrm{it}}+\alpha_{11} \mathrm{MTaiwan}_{\mathrm{it}}+e_{i t} \\
& \text { NChinaI }_{\text {it }}=\beta_{0}+\beta_{1} \text { ITC }_{\text {it }}+\beta_{2} \text { RUDIS }_{\text {it }}+\beta_{3} \text { NTaiwan }_{\text {it }}+\beta_{4} \operatorname{CInvRev}_{\text {it }}+\beta_{5} \text { ETR }_{\text {it }}+\beta_{6} \text { DE }_{\text {it }} \\
& +\beta_{7} \text { GROWTH }_{i t}+\beta_{8} \mathrm{SIZE}_{\mathrm{it}}+\beta_{9} \mathrm{CINT}_{\mathrm{it}}+\beta_{10} \mathrm{DOIL}_{\mathrm{it}}+\beta_{11} \mathrm{MChina}_{\mathrm{it}}+\mathrm{e}_{\mathrm{it}}
\end{aligned}
$$

Based on Table 4, higher DITC ratio (ITC) change companies had more investment numbers in Taiwan (NTaiwan) but fewer investment numbers in Mainland China (NMainland China). This result exhibited that the DITC of the IITS benefited to the Taiwanese shareholders and reduced the dividend double taxation. There were more Taiwanese investment numbers rather than in Mainland China ones. The higher URE ratio (RUDIS) change companies had higher retained earnings cost, increased the cost of the capital accumulation, and impaired the plant expansion. However, the empirical results indicated that the higher URE ratio (RUDIS) companies had more investment amounts in Taiwan opposed to the hypothesis. The possible reason was that the internal capital cost was lower than the external capital cost. The business was still willing to pay the URE tax and sustain the internal capital fund. There were more investment numbers in Taiwan, and lesser investment numbers in Mainland China significantly. Regarding the firm-specific characteristics variables, larger size companies had more investment numbers in Taiwan. Furthermore, the financial environment in Taiwan was better than in Mainland China and higher debt-to-equity ratio companies had more investment numbers in Taiwan but fewer in Mainland China. The rest empirical findings were consistent to the Table 3.

Table 4. Regression results of the investment numbers in Taiwan and Mainland China.

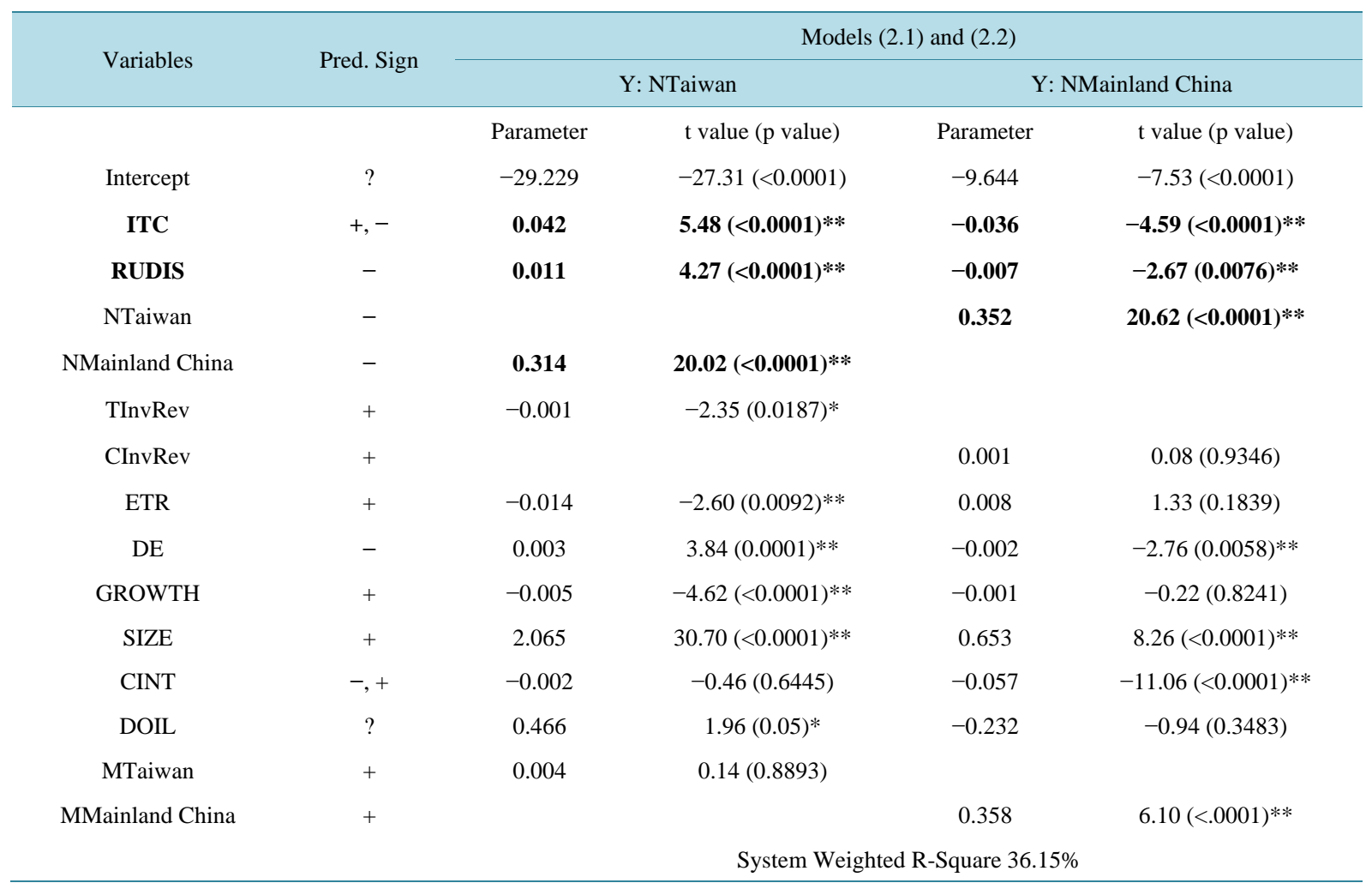

Note 1: NTaiwan: the numbers of investment companies in Taiwan; NMainland China: the number of investment companies in Mainland China. All other variables are defined in Table 1 Note 1 . Note 2 : *5\% significance level; **1\% significance level. 


\section{Conclusions}

In 1998, the Taiwanese Ministry of Finance enacted the Integrated Income Tax System (IITS). The tax system had two important features: the dividend imputation tax credits (DITC) to Taiwanese shareholders and the $10 \%$ surtax levied on undistributed retained earnings (URE) in the Taiwanese businesses. We examined the impacts of the DITC and URE on the capital investment of Taiwanese businessmen to investment both in Taiwan and Mainland China. We utilized the financial data from 1998 to 2008. The empirical results exhibited that the DITC diminished the corporate dividend double taxation and lowered Taiwanese shareholders tax burden. The DITC privilege did not apply to the Chinese investment. We found that higher DITC resulted in higher capital investment in Taiwan and lower one in Mainland China. Based on DITC, the Taiwanese capital investment was promoted. In order to compensate the tax loss of DITC, there was 10\% surtax of URE. This policy increased the internal fund cost, lowered the capital accumulation, and impaired the capital investment. After our empirical study, the results indicated that the higher URE led to higher Taiwanese capital investment, opposed to our expectation. The imposed $10 \%$ surtax mission was to prevent the big shareholder to hold retained earnings. The policy still did not accomplish the goal. The business still sustained the retained earnings for future internal fund usage. Compared to Taiwan, higher URE ratio led to lesser capital investment ratio in Mainland China but not in statistics significance. The reason might be the regulation to Chinese investment up to $40 \%$ of net worth. This policy affected that the Chinese subsidiary was reluctant to wire back to Taiwanese parent company. They would reinvest the profits in the plant expansion and enjoy $100 \%$ tax reimbursement. This tax addition did not significantly reduce the Chinese capital investment. Our empirical finding supported that the DITC led negative impact to the Chinese capital investment. Nevertheless, the DITC was not the only determinant to Chinese investment consideration. Our results might serve the authority to reconsider and modify the related tax policies such as: wire back profit charged tax and $40 \%$ of net worth investment limitation to Mainland China. The ultimate goal of a tax policy-IITS is to improve the economy (Schulman, Thomas, Sellers, \& Kennedy, 1996).

One limitation of this study was from the data resource. Our study data were derived from the TEJ database. This database collected Chinese investment data since 1998. Therefore, we might not analyze the periods before and after IITS in this study. Due to the tax reform, another limitation was inherent from the ceteris paribus assumption (Tung \& Cho, 2000).

\section{References}

Altshuler, R., \& Fulghieri, P. (1994). Incentive Effects of Foreign Tax Credits on Multinational Corporations. National Tax Journal, 47, 349-361.

Babcock, J. (2000). The Effects of Imputation Systems on Multinational Investment, Financing, and Income-Shifting Strategies. The Journal of the American Taxation Association, 22, 1-21. http://dx.doi.org/10.2308/jata.2000.22.2.1

Black, E. L., Legoria, J., \& Sellers, K. F. (2000). Capital Investment Effects of Dividend Imputation. The Journal of the American Taxation Association, 22, 40-59. http://dx.doi.org/10.2308/jata.2000.22.2.40

Boyle, G. W. (1996). Corporate Investment and Dividend Tax Imputation. Financial Review, 31, 209-226. http://dx.doi.org/10.1111/j.1540-6288.1996.tb00871.x

Carlson, S. J., \& Bathala, C. T. (1994). Impact of the Repeal of the Investment Tax Credit on Firm's Investment Decisions. Journal of Applied Business Research, 10, 33-39.

Chang Jui-Tang, Tseng Yu-Chi, \& Huang Tien-Fu 張瑞當, 曾玉琦, 黃天福 (1999). 我國兩稅合一新制對投資意願影響 之實證研究. [An Empirical Investigation of the Integrated Income Tax System on the Effect of Investment]. Jingji Qingshi ji Pinglun, 4, 200-224.

Chang Keh-Jen 張克偵 (1997). 兩稅合一與企業經營效益. [The Integrated Income Tax System and Corporate Operation Performance]. Kuaiji Yanjiu Yuekan, 134, 64-66.

Chen Chung-Chin 陳忠勤 (1997). 新稅制 兩稅合一之剖析(上). [New Tax: Analysis of Integrated Income Tax System (I)]. Kuaijishi Huixun, 1-6.

Chen Chung-Chin 陳忠勤 (1997). 新稅制 兩稅合一之剖析(下). [New Tax: Analysis of Integrated Income Tax System (II)]. Kuaijishi Huixun, 1-18.

Chen Tu-An 陳聽安 (1985). 我國所得稅制改革的可行途徑. [The Methods of Income Taxes Reform in Taiwan]. Caishui Yanjiu, 17, 12-20.

Cheng Yueh-Sui 鄭月遂 (1996). 談兩稅合一的架構與實施的時機. [The Structure and Implementation of the Integrated 
Income Tax System]. Zhongguo Shuiwu Xunkan, 1616, 12-15.

Collins, D. W., \& Kothari, S. P. (1989). An Analysis of the Intertemporal and Cross-Sectional Determinants of the Earnings Response Coefficients. Journal of Accounting and Economics, 9, 111-139. http://dx.doi.org/10.1016/0165-4101(87)90002-4

Gupta, S., \& Hofmann, M. A. (2003). The Effect of State Income Tax Apportionment and Tax Incentives on New Capital Expenditures. The Journal of the American Taxation Association, 25, 1-25. http://dx.doi.org/10.2308/jata.2003.25.s-1.1

Harrison, L. H. (1990). A Policymakers View of the Cost of Capital. Proceedings of the American Council for Capital Formation Symposium on Business Taxes, Capital Costs, and Competitiveness, Washington DC, 1 May 1990.

Hsu Wen-Yu 徐文友 (1996). 兩稅合一制度之探討. [Investigation of the Integration Income Tax System]. Zhongguo Shuiwu Xunkan, 1613, 12-13.

Huang Tien-Fu 黃天福 (1998). 我國兩稅合一稅制對投資意願影響之探討. [The Study of the Integrated Income Tax System to the Investment Influence]. Unpublished Master's Thesis, Kaohsiung: National Sun Yat-sen University.

Rosacker, R. E., \& Metcalf, R. W. (1993). United States Federal Tax Policy Surrounding the Investment Tax Credit: An Empirical Investigation of Enactment, Rate Enhancement, and Repeals. Advance in Taxation, 5, 219-246.

Schulman, C. T., Thomas, D. W., Sellers, K. F., \& Kennedy, D. B. (1996). Effects of Tax Integration and Capital Gains Tax on Corporate Leverage. National Tax Journal (1986-1998), 49, 31-54.

Shoemaker, P. A. (1991). Investment Tax Credit Effects on the United States and Canada, 1968-1985. Journal of Applied Business Research, 7, 56-66.

Shoven, J. B. (1990). Alternative Policies to Lower the Cost of Capital Cost, and Competitiveness. Washington DC.

Tung, S., \& Cho, S. (2000). The Impact of Tax Incentives on Foreign Direct Investment in China. Journal of International Accounting, Auditing \& Taxation, 9, 105-135. http://dx.doi.org/10.1016/S1061-9518(00)00028-8

Wang Chien-Tung 王建棟 (2003). 兩稅合一對資本投資與股利政策影響之實證研究. [The Impact of Imputation Tax System on Capital Investment and Dividend Policy]. Unpublished Master’s Thesis, Taoyuan City: Chung Yuan Christian University.

Wang Jui-Chih 汪瑞芝 (2006). 兩稅合一制對公司資本投資影響之實證研究. [An Empirical Investigation of the Integration Income Tax System on Firms’ Capital Investment]. Zhonghua Guanli Pinglun Guoji Xuebao, 9, 1-18.

Wu Chiuh-Wo 吳去我 (1997). 兩稅合一稅收損失官商認知差距大. [The Tax Loss Recognized Difference between Government and Corporate of Integrated Income Tax System]. Zhongguo Shuiwu Xunkan, 1654, 11-12.

Young, K. H. (1988). The Effects of Taxes and Rates of Return on Foreign Direct Investment in the United States. National Tax Journal (1986-1998), 41, 109-121. 